ve. No es un hombre vulgar, y por eso su época no lo comprende; eminentemente subjetivo-narra sus sentimientos, alegrías, dolores $y$ penas-, logra la máxima expresión de la idea en la mayor concisión. En toda su poesía-prosa o versola forma no es más que el medio de expresión de la idea. Esta es la principal; aquella, aunque bellísima y perfecta-no tanto que no haya escritores que lo superen-, es lo secundario. Por eso emociona la poesía de Becquer: porque tiene alma, sentimientos, antes que palabras. Su poesía es para todos, ya que busca sencillez y claridad y no el empleo de palabras ede diccionarios, como otros "cultos» escritores.

Pero esto no quiere decir que no haya arte en su expresión. La hay, y no poca-Cartas literarias. Eminentemente descriptivo, parece, a veces, que a medida que narra, se construye ante nosotros lo narrado-Tres fechas, El beso, El monte de las ánimas, La ajorca de cro, Creed en Dios.

Su poesía, como el órgano de Maese Pérez, empieza a sonar reposada, tranquila, se sostiene en un trino prolongado y termina abriéndose en una explosión de belleza y sentimiento.

\section{DESVIACIÓN DEL CINEMA}

En el mismo número, Javier de Echarri hace algunas interesantes observaciones sobre Desviación del Cinema en que se manifiesta desconcertado ante la trayectoria seguida por el cine últimamente, $y$ pronostica el fracaso del cine sonoro y realza la importancia, como arte, del cine mudo. Al respecto afirma:

La evolución del cine hacia el teatro no es sino retroceso a un arte menor, porque actualmente el cine es un arte conseguido, $y$ el teatro, no.

La plasticidad, unida al suceso escueto y la belleza total, son patrimonio del cinema, y pueden (deben) serlo del teatro. $\mathrm{La}$ reacción (es una reacción) del cinema sonoro es la negación de todo esto.

No cabe la menor duda que el ruido, el sonido, llevará siempre sobre su conciencia el haber adulterado un arte que era superación de artes.

Con su nueva senda, el cine va póco a poco a ocupar un lugar que también poco a poco, va abandonando el teatro, $y$ que el teatro abandonaba para llevar a ese lugar que ahora va abandonando el cinema. He aquí la catástrofe.

\section{CONTRA MARAÑóN}

En el otro número de Nueva Revista que conocemos, Luis Filgueira, uno de los directores de la publicación, se refiere en un interesante artículo titulado La inmaculada juventud a ciertos problemas de interés permanente para los jóvenes, refutando en parte principal de él una conferencia del famoso doc. tor Marañón. Dice en sus párrafos principales:

Don Gregorio Marañón, que $\tan$ sanos consejos nos ha dado siempre, habla desde un libro-ya lo había hecho antes en una conferencia-de Los deberes de la juventud, entre otros temas ensartados por la palabra spreocupación", y nos dice que el principal deber del joven es la rebeldía. Yo veo que la rebeldía no es el deber de la juventud, sino el deber de todo hombre-ciudadano - ante la injusticia. Pero como a la vejez - dice - corresponde la adaptación, he aquí de qué manera tan cómoda tranquilizan su conciencia 
los hombres que no se han rebelado cuando debieron, hombres en quien la juventud tenía puestos sus ojos creyéndolos fuertes $y$ capitanes.

No; el deber de la juventud no es la rebeldía: es la vehemencia; porque precisamente por tener un organismo joven, fuerte, elástico e indócil, debemos de sostener nuestras convicciones-creadas en los jóvenes de hoy por nosotros mismos, gala que tenemos al no deber nada a los que fueron jóvenes diez años ha- con energía, pero nunca rebelarnos por instinto, y si éste surge, aquí la voluntad.

Afirma Marañón que los jóvenes de hoy no debemos de ser deportistas, precisamente porque estamos bajo el imperio del deporte. Yo opino que seremos o no seremos deportistas, si creemos en los beneficios o perjuicios del deporte, respectivamente. Pero siempre la idea que de él tengamos la sostendremos con fuerza y la razonaremos con toda clase de argumentos, para salir victoriosos de la discusión, o para, por lo menos, creer que hemos salido victoriosos. Marañón mismo echa por bajo la sinrazón de su afirmación al decir un poco después que no se entiende la palabra rebeldía en el sentido de ir contra los rojos por el hecho de que mandan los blancos. Pero aun hay más: no creo exista cosa más contraria a toda clase de rebeldía que la milicia, a la que Marañón admira, porque catenúa hasta límites peligrosos el impulso eficaz de la personalidad». iAh, la personalidad!, la destacamos tanto los jóvenes y los viejos, que si no fuese un defecto de la época y una mala costumbre de la sociedad, nos parecería lógico que fuese un vicio.

Veamos ahora otras afirmaciones erróneas que de la juventud hace Marañón en el mismo ensayo, afirmaciones, a mi juicio, equívocas: -El joven no suele ser apto para las finas emocioness, y más adelante: -Se dice que la juventud es la edad del amor; pero esta verdad se re- fiere exclusivamente a los componentes imaginativos y sentimentales... No creo que haya otra más fina emoción que la del amor, el amor en lo que tiene de espiritual y más aun cuando todos los amores que se tienen en la juventud-los primeros, siempre los primeros-son del más fino sentimentalismo. Cierto que más adelante surgen otros cariños más espirituales tal vez, pero sólo cariños análogos de sentimientos de paternidad.

Según esto, pues, quiere decir Marañón que el joven no se emociona con la juventud; esto es falso: creo en el espíritu de caridad latente en el corazón de los jóvenes, caridad en su forma más sublime, la que no analiza, desnuda de esperanza.

Refiérese don Gregorio Marañón a la política, y cree en la necesidad de mentalidades avanzadas y conservadoras, en contraposición, jóvenes y viejos. Conservar cosas viejas-no antiguas, viejas-no debe permitirse ni aun a la senectud; de aquí nuestra sed de renovación. Pero el conservadurismo de las ideas renovadoras lo tendremos nosotros cuando pasemos de la juventud, como nuestros hijos y nietos. Ya nos encargaremos los jóvenes de hoy de entregar a las generaciones venideras un legado limpio de política, en que no sean necesarias las contraposiciones, sobre todo si éstas han de depender del matiz edad.

Sucede que en lo que a política se refiere, actualmente, algunos sólo se ocupan del momento, hay una gran mayoría que ha adoptado en lugar del criterio adaptación este otro: comodidad.

Un alto ejemplo de rebeldía en la vejez nos lo ha dejado nuestro llorado Andrenio, y aún creo que, a pesar de todo, nos lo dejará también D. Gregorio Marañón cuando a ella llegue. El Gregorio Marañón que nosotros hemos conocido hasta la publicación del libro Amor, Conveniencia y Eugenesia. 
Voluntad. A la voluntad alude Marañón cuando finaliza este ensayo, pero la necesitamos todos, jóvenes, maduros y viejos, en el hombre y en la mujer, para ponernos en nuestro lugar, para comportarnos con los que están en otra edad, para el trabajo, para el dolor, para el estudio. Voluntad para dejarlo todo antes de acomodarse a lo ilegal, vehemencia juvenil en todas las edades para oponerse a la injusticia.

Es de esperar que la juventud española pueda cumplir las promesas contenidas en las bellas palabras de Filgueira que hemos transcrito.

\section{Sobre J. C. Mariátegui}

Un grupo de escritores jóvenes del Perú, César Barrio, Jorge Basadre, Carlos Raygada, Luis Alberto Sánchez, nuestro conocido, y Alcides Spelucin, han fundado un periódico, Presente, calificado de «inactual» por sus fundadores, y en el que, dándole una orientación francamente crítica y artística, se proponen formar un grupo, grupo de acción cultural, que seguramente será tan necesario en Lima como en Santiago. Entre nosotros, el propósito similar ha sido cumplido con la publicación de Indice.

En el número que tenemos a Ia vista, de Julio del presente año, destaca un estudio de Luis Alberto Sánchez, sobre Mariátegui, titulado Datos para una semblanza de $J$. Carlos Mariátegui, del cual extractamos los párrafos principales:

Para seguir más de cerca la orientación y la obra de José Carlos, es preciso prescindir de la devo- ción beata, de la emoción intensa y decisiva de los primeros instantes, intentar un bosquejo de su evolución, objetivamente, marcando los hitos, a fin de no incurrir en ninguno de los dos extremos en que fácilmente se cae cuando se roza una personalidad de tal calibre.

Relata la infancia de Mariátegui, sus debilidades físicas que lo acompañaron desde su nacimiento, y su iniciación, allá por 1910 , como periodista en La Prensa.

En La Prensa pontificaban, en esos días, La Jara, Yerovi, Cisneros; Piérola y sus conspiradores; Ulloa y sus editoriales. Los poetas predilectos de entonces-lo fueron también de Mariátegui-Herrera Reissig, Darío y Chocano, llenaron su imaginación de frases sonoras y giros rebuscados. Amanecía un americanismo retórico. La generación de Ariel-los García Calderón, Riva Agüero, Bealunde, Gálvez-imponía el sello de su aristarquía en Lima. Era la hora cenital del modernismo y el decadentismo; de la sonoridad verbal. El cojito Mariátegui atisbaba desde su rincón de pinche del periódico, a los escritores universitarios orgullosos de entonces. De ahí nació quizás su primera disconformidad con lo universitario y con el seudo americanismo.

Permanece en el periodismo Mariátegui, y su tendencia frívola y literaturizante se manifestaba en sus crónicas (firmaba eJuan Croniqueur 3 ) y en la vida de bohemia literaria que hacía junto con sus compañeros de letras, Valdelomar, Ladislao Meza, More, etc. Pero ya lo dominaban las inquietudes sociales y cuando se fundó el Partido Socialista ,peruano reclamó un lu- 